\title{
The Maya Idea of Culturally Sustainable Development
}

The concept of culturally sustainable development, as it is articulated by $E l$ Centro Pluricultural para la Democracia, will be presented in this chapter. The method of analysis here will involve the depiction of conceptions that have emerged out of my interviews and focus groups, as well as texts of $E l$ Centro. Specifically, concepts related to the following questions will be presented: what is the relationship between humans, nature, and culture? What is Mayan culture? What is development? How do you do development? The goal here is to depict, as closely as possible, the thinking of El Centro regarding these concepts.

Clearly, issues related to the ability of Western trained academics to represent the thinking of indigenous activists must be addressed here. A multifaceted and participatory methodology was developed in an attempt to address these issues. The process of interpretation involved, first, a three-month period of participant observation at El Centro; second, a thorough reading of all of El Centro's publications; third, individual interviews with members of the organization; fourth, a preliminary interpretation of the concepts; fifth, a presentation to members of El Centro of this preliminary interpretation; and, finally, a focus group discussion of these interpretations was held in which members changed, critiqued, and approved or disapproved of the author's representations and interpretations. The following depiction of the theory of culturally sustainable development is the result of this process.

(C) The Author(s) 2020

T. MacNeill, Indigenous Cultures and Sustainable Development in Latin America, https://doi.org/10.1007/978-3-030-37023-7_7 


\section{Human, Nature, Culture}

When beginning the process of discerning the meaning of culturally sustainable development in the initial phase of fieldwork, it seemed logical to first establish the properties of the fundamental unit of development-the human being. To do this, it would be necessary to hold the concept of culture to the side. It became clear early in the interview process, however, that to sever these concepts from one another would be to do violence to the idea of CSD. Of course, in the construction of the categories and typologies that are necessary for academic work, we regularly make somewhat arbitrary distinctions. The trick is to know when such distinctions cross the line between reasonable categories for analysis and unacceptable misrepresentations. In the course of investigation, it became increasingly apparent that treating culture and human as separable would be to cross that line. The same, it should be understood, could be said for creating a false distinction between humans and nature, or culture and nature for that matter.

Considering this, it is important to remember the words of Matea when she was asked to explain what she thought a human to be. "Everything to do with the human being," she said, "has to do with the spirit; has to do with nature." Similarly important is the example that Mario used to convey the inseparability of natural materials and cultural understandings of them. "Take the stone in the vision of the Mayan world," he suggests,

In the Western world it is a material, a mineral that has no value. In Mayan culture, the stone, if it has use, it has use because it is complementary to the culture; and it is complimentary to the culture because we use it.

In Mario's comments, we see a claim that use-value is imbued on an object by the virtue that it has cultural value. But it is not presumed to be a unidirectional relationship. There is dialectic here-the cultural meaning of a material thing stems from its usefulness, and its usefulness is culturally determined. To speak of one is to speak of the other. As we address issues of culture and humanity here, then, we must be cognizant that we are speaking at the same time of the hard materiality of the natural world, of culture, and, as Matea suggests, of "the spirit."

Similarly, the division between individual and community is ambiguous. When the members of El Centro speak of human beings in the context of their work, they speak of "social subjects." True to the sense of 
ambiguity around the concepts of human and culture, a social subject can be a single person or a group of people. Each of the members of El Centro, for example, would be considered a social subject, but so too would the organization itself. Social subjects are "social" both in the sense that they may actually be a group of people, but also in that, as Matea suggests, "culture provides the elements for the formation of subjects." The culture, community, and person are inseparable. As Sofia understands it,

much of what is a person, of what is a community, is the culture. Therefore you cannot separate it. ... You cannot say, "good, I am going to leave the culture here and develop over there". This is impossible because the culture is part of you; of your ideology; of your form of being. And therefore, if you propose ideas of how to generate development in your community, you will do it from the place of your culture, because you are there, and you identify with it, and it is from this point of view that you have generated an idea of how to generate changes that include the culture. You cannot pose questions that are not in accordance with the reality in which you live. Therefore into all of all you propose goes the culture. It is part of you and you cannot leave it to one side.

Matea elaborates more on the elements of culture, describing culture as "the social organizing processes that are given at the level of the community." These include "expressions that mark differences from other cultures based on the form of life, the form of sustenance, the spirituality, the customs," as well as "traditions and all the organization that you have at the level of the villages."

Cosmovision is an integral part of culture. Whereas culture represents the totality of meaning in a locale, cosmovision, Matea continues, is "the form of seeing all themes that are given in the world-perception. This exists in every part of the world ... there is a cosmovision in all places." Cosmovision is a subject's understanding of the way in which the world functions, and it is constructed of the pieces of culture. As Roberto explains, your culture is "your language, [and] your clothing," but also "your way of thinking-you have to see with your cosmovision." And, he continues, your cosmovision informs "your own way to conceive of your relation to the natural world."

But to say that subjects are socially formed is not to say that they are simply determined by their cultural environment. More than this, as Mario explains, subjects, 
are those who act. Who do [things].... The subject is an element, is a cognitive subject that has experience, has ideas, has thoughts. And a subject is a motor. The motor of his or her own development. ... The subject is the people. [The subject and the culture] are the same thing; subjects are the members of a culture.

Similarly, Maria insists that culture is created by "the population"-that it is created by subjects with agency. This is done, however, "in accordance with [a community's] thoughts and customs." It is with cognitive tools based on "the practices that have developed," she continues, "that the culture of a community is made."

For the members of El Centro, such assertions are much more than attempts to conceptualize structure and agency problems in academic theorizing. Cultural devaluation or cultural loss is necessarily a personal imposition. It is personal devaluation. It is a felt personal loss for members of communities who hold such cultural practices. Culture, for the members of El Centro, is valuable in itself, and must therefore be protected. This is evident in Maria's response when asked why it is important to protect culture:

Because the culture forms part of the person, therefore the culture carries values, carries principles and this must not be forgotten in the development process but must be maintained, and because it forms part of the identity of the people, the view of the culture must not be lost.

It would be easy to misinterpret this as an assertion that cultures must not change-that they must remain static. This would not be consistent with the thinking of members of El Centro, however. Sofia, for example, holds that cultures do change-just not "from night until morning." After evoking the idea that the "essence" of Mayan culture is in the cosmovision, Matea draws attention to the tendencies of cultures to change, and what she perceives to be the true problem related to this-inequality:

I think that all cultures should have independence. Not that they are going to be static or that they will maintain uniformity. But that they will not change their essence. When they lose their essence, they become debilitated and fall into the other culture. I feel that this should be changed, because at the level at which we are working there exists a large culture, but also a small culture. And often what happens is that the large culture absorbs the small culture. Like ideology, I speak of all the subliminal messages that provoke 
consumerism in us but also of more radical things that are possessed by other cultures. I speak of wars, I speak of impositions through financial resources. These things impact the entire country and prevent it from advancing. Therefore the cultures do not seem equal. It is this way because the one that has greater resources and greater numbers, greater financial resources, is often the one that maintains the hegemony. The survival of the small one is hard to achieve, and a lot of struggle is required if it is to survive.

Although it is not clear if the "larger" culture Matea refers to is Western culture, or ladino culture, or both, the statement draws attention to the hard material and cultural realities related to CSD in Guatemala. "Cultures are going to change," she continues, "depending on the moments and the processes in which each of these peoples exists." It is in this way, she argues, "that we have had to be learning from other forms." However, she insists that this process of cultural interchange has, "in some cases, done much damage to us."

The cases in which damage has been inflicted have occurred amidst great material and hegemonic power imbalances according to Matea. Roberto expands on the co-determining nature of material and cultural power, and the difficulty of the subordinated to engage in the production of culture. An idea of development that is culturally sustainable, he argues, must come from the people, but "sadly," he explains, "we don't have one to tell you about." Furthermore,

The theory of development from the perception of the indigenous Mayan peoples in Guatemala is [non-existent] because there are no conditions, resources, or means of production. Otherwise it would be possible in this moment to have all the conditions necessary to initiate it.

Such an assertion brings the struggle for development undertaken by $E l$ Centro not just into the realm of the cultural or ideological, but into the material simultaneously, as is evident in the following statement from Roberto:

The international economy or free market or international market has its own strategy of enrichment, of accumulation of resources. The strategy is to generate consumerism in the population. This is not development. If I am earning four thousand Quetzales and at the end of the month I buy a big television, or a large sound system, or other things, I have already spent my paycheck. I think this is a way in which local people spend money on items 
that are not useful for survival in this society. Survival and achievement of a better life do not depend directly on these things. Therefore I think that the strategy of consumerism in the population has been generated only for the benefit of foreign capital.

In Roberto's opinion, cultural and material imperialism not only rob indigenous Maya of their culture, but of the fundamental sustenance necessary to assert their own culture and their own idea of development. A form of development is nurtured in such a situation, but it is one in which "I have nothing to eat, I have nothing for education, I have nothing for health, but I am interested in equipping my house." In such a situation, members argue, the fight for development is lost. Indigenous culture is devalued, and indigenous people become subordinately integrated into a global economy that is structurally bent on material exploitation and cultural domination. Subjects have been nurtured in this situation-but they are of the wrong kind. They are not the "political subjects" that CSD requires, as Maria explains,

When we speak of political subjects it is when they already have a greater capacity — of participation, of decision, of impact. Therefore the culture may create subjects, but [not] political subjects, [which] are created at the level of leadership.

Both cultural and material domination, then, are thought to undermine the creation of subjects which would be endowed with the agency required to conceive of, and then direct, their own development. Hegemonic messages of global consumer culture are presumed to bury and devalue local indigenous culture, while diverting material resources away from the reinforcement-through-use of local culture and towards the purchase of mass-produced consumption goods.

The concept of culture, and the politics that surrounds it, can now be more clearly delineated in a way that attempts to depict the meaning ascribed to it by members of El Centro. In a publication on culturally sustainable development, culture is described in this way by El Centro:

Culture is a form of life, a manner of being, a way of thinking and feeling, and a different style of doing things throughout the day. That is to say, it is the solution that every community or group of humans gives to their relation to one another and with nature. Understood in this manner, culture is a social product that unites values, beliefs, attitudes, and behaviours of a 
society determining its development. Therefore, culture is dynamic, that is to say, it changes. (CPD 2008, p. 21)

The appearance of the word solution, and culture's depiction as a product that unites values in a society, thus determining its development, might lead one to assume this to be an instrumentalist definition of culture. That is, it may look like something akin to new institutional economics. When contextualized with the interview materials presented earlier, however, it seems more probable that the solution here is not to the problem of "how do I get more of what I want?" Rather it is a solution to the questions, "how do I make sense of the world?" "how should I act in the world?" and "what do I value?" The answers to these questions change, but not "from night until morning," and such changes can most likely be thought of as positive if they are undertaken in an environment that is relatively devoid of material and discursive inequalities such as income inequality or racial prejudice. This is to say that culture and cultural change are judged positively when the social subjects that are composed of, and compose, culture have "equality of agency" in the construction of that culture-to borrow a term from Rao and Walton (2004).

The development that is determined in this definition of culture is not a quantitative measure such as a level of gross national product or aggregated community income. It is qualitative-culture informs the kind of development that is sought. Culture is not subordinate, nor is it separable from the material world. There is great concern at El Centro that the urge to purchase Western consumer products can cause subjects to misallocate their resources away from the provision of healthcare, food, clean water, or education, for example. A culture of consumerism is chosen here at the expense of what are seen to be the fundamental elements that provide for life. Even this, however, does not reduce to a critique of "good" indigenous culture versus bad consumer "culture." Roberto, for example, reluctantly admits that this is "a type of development." The more fundamental issue for members of El Centro is that one of these "cultures" is exorbitantly strong, dominant, hegemonic. In such instances, Matea explains, "there is a psychological bombardment on us, therefore we learn another distinct form of life, that we consider better than our own." This undermines the capacity for the local culture to adapt in a democratic way-one in which values can be reevaluated and problems can be negotiated in a climate of relative discursive and material equality. 
What becomes apparent from this discussion is that for any action to be "culturally sustainable," it must facilitate a discursive equality in which indigenous culture and knowledge are not subordinated, overpowered, or dominated. Market-led development is perceived to carry with it Western consumer culture that is backed by material power. Development of this sort is not considered to be culturally sustainable because of the felt devaluation of indigenous culture and its submersion in the hegemony of Western capitalist consumer society. The same could be said of development plans that emanate in a top-down manner from Western-trained development practitioners-be they rooted in liberal or Marxian theories. Such interventions, well-intentioned as they may be, carry with them a discursive force that is backed by economic power. They, therefore, threaten to devalue local knowledge and culture. For development to be culturally sustainable in Guatemala, Roberto claims, it must "come from the perception of the indigenous Mayan peoples ... from the communities; the majority of which are indigenous communities."

The "perception" of indigenous communities is thought still to be rooted in Mayan cosmovision. Members of El Centro maintain that despite cultural and material intrusions from Spanish colonialism, Christianity, consumer culture, resource-extracting corporations, and civil war, the core of Maya cosmovision remains intact, if buried, in the subjectivities of the residents of indigenous communities. The continued existence of the communal mayorship in most communities is offered as proof of this. So too is the use of traditional clothing and the perseverance of indigenous languages throughout the highlands. All of these institutions and practices, it is argued, have changed somewhat with external interaction, but have been maintained, almost miraculously, throughout over 500 years of what members characterize as planned and deliberate ethnocide. This cultural maintenance in the face of planned destruction has been done through a creative incorporation and blending of cultural elements as Matea explains regarding religion:

In Chichicastenango, for example, inside the church are all the [Christian] images and pictures, while the altar outside is Mayan. Both the churches and Mayan alters were put on the highest points in town-the same places. And you see a combination of the two traditions. You see Mayan priests and the people doing Mayan ceremonies, and then go to the church. Or they may just go to the church but engage in Mayan ceremonies. 
Mayan cosmovision, then, is thought to remain embedded to varying degrees in the subjectivities of contemporary indigenous Guatemalans, even those who practice Christianity. As discussed in the previous chapter, a felt connection to the natural world and cosmos, as well as egalitarian, harmonious tendencies, is assumed to be integral to that belief system.

\section{Participation, Democracy, Development}

The very fact that the cosmovision has become subordinated to colonial belief systems represents a fundamental inequality to the members of $E l$ Centro. Attempts to re-valorize the cosmovision in the eyes of ladino and Maya populations are, therefore, fundamental to CSD. This "principal objective," as Mario calls it, has been integrated into every part of $\mathrm{El}$ Centro's operations. But perceived damages to nature are also threats to CSD - not simply in that they may compromise the abilities of future generations to realize their own development, but because nature and culture are one according to the cosmovision. To damage nature is to damage part of the culture, and to damage culture is to damage the person that is integral to that culture. As was discussed in the last section, only a development that takes place in an environment of discursive and material equality can, therefore, be considered culturally sustainable, as Mario suggests:

Culture has its own value. ... When the people already value and come to value their own form, then a great measure of development with culture will have been achieved. This is because without respecting their own culture, the people will be alienated. That will be monocultural-looking for only one culture and not diversity. Diversity is force. With diversity there are various visions of the world, for example, you can not submit me to your vision of the world, and I cannot submit you to mine. ... If we know how to achieve diversity with respect, with harmony, with coexistence in peace, then development is better.

To recapitulate a fundamental point, CSD does not imply the freezing of culture (or nature, or politics, or the economy for that matter). Nor does it suggest a complete reversion to some imagined pre-Columbian state. It involves the equalization of discursive and material power relationships between indigenous peoples with their nature/cultures and hegemonic Spanish colonial and global capitalist systems. Sustainability means continuity amidst constant cultural and natural change. CSD, therefore, does 
not imply a particular cultural or economic form, but rather a transformative participatory process of deep democracy, as the organization explains in one of its publications:

If we understand participation as an essential element democratic system, we can say that this makes all the people and the political community as a whole, the protagonists of different social processes. All must be involved closely in the cultural, political, economic, and environmental aspects of group life. It is this involvement that, more or less, marks the advance of democracy in a given society. (Chávez Cayax 2003, pp. 8-9)

During El Centro's workshops that are set to promote democratic participation, traditional elements of the cosmovision are encouraged. The intimate relation of indigenous peoples to the land is reaffirmed often, for example. This is done not to "freeze" a primordial culture but to attempt to counter the hegemonic imposition of Spanish-colonial and Western capitalist ideologies which have conspired to devalue indigenous belief systems for 500 years. The value of pre-Colombian institutions such as the communal mayorship is reasserted in an attempt to revalorize Mayan culture as well. But so too is the value of international human rights architectures, democracy, and positive change. These are all things that are commonly associated with "modern" or "Western" culture, and they are things that do not imply stagnation.

The core of the goal of El Centro's development work is, in fact, to encourage a culture and politics of "transformative participation" - not a cultural ossification. It is hoped that this transformative process would go beyond the "pseudo-participation" of stakeholders being simply invited into the decision-making process "for the photo," or merely being consulted, being given charge of delegated tasks in larger processes that have been conceived from "above," as Chávez Cayax (2003) argues in one of El Centro's publications. As Chávez Cayax (2003) continues to explain, "transformative participation" requires political subjects who are "actors, not spectators" in decision-making processes at all levels, and this involves the building of capacities of traditional and local institutions and countering discursive structural barriers by valorizing indigenous culture and combating racism (pp. 10-12).

A legal architecture does exist, which provides a framework from within such participation can take place. And these legal texts are utilized extensively by El Centro in its interaction with communities. In Article 46 of the 
Guatemalan constitution "it is established as a general principal in matters of Human Rights, that the treaties and conventions accepted and ratified by Guatemala have preeminence over internal rights." Often referred to by members of El Centro, Articles 20 and 21 of the Universal Declaration of Human Rights, ratified by Guatemala in 1994, establish "freedom of association and the right of participation in governing the country" (Chávez Cayax 2003, p. 22). Members insist that this right is not restricted to voting but to "participate in the decisions that are made in the State, and to obtain the form of organization desired by all the inhabitants that form the country" (Chávez Cayax 2003, p. 23). The Guatemalan Constitution also guarantees the right of meeting and manifestation of collectives that may present petitions and grievances to government, the right of free association (Articles 34, 35, and 44), the right of a person to participate in the creation of their cultural identity (Articles 57, 58, and 66), and rights of collective participation (Articles 136 and 136).

As discussed in the previous chapter, ILO 169 is commonly evoked by El Centro in texts, interviews, and meetings. The agreement contains language protecting culture, traditional lifestyles, consultation, participation, and control over economic, cultural, and social development processes. Although some of the interpretation of the agreement has been contested in the Guatemalan context, it is insisted at El Centro that ILO 169 contributes to the creation of space in which political participation can be undertaken.

Agreements negotiated under the Peace Accords also provide space for wide political participation in Guatemala. The interrelated agreements of the Accords convey a deep discourse of indigenous rights, decentralization, cultural affirmation, and community self-management. Guatemala agreed to become a signatory of the Universal Declaration of Human Rights, as a part of the Peace Accord negotiations in 1994. The Guatemalan Accord for the Identity and Rights of Indigenous Peoples was signed in 1995. The Accord of Agrarian Socioeconomic Aspects and Situation and the Accord for Strengthening Civil Power and the Function of the Exercise of a Democratic Society were signed in 1996. The Law of Councils of Urban and Rural Development, the General Law of Decentralization, and the new Municipal Code were signed in 2002.

The purpose of this chapter is not to go into detail on arguments regarding legal interpretations of these accords and conventions. The essential point regarding these instruments is that they all attempt in some way to create legal space for direct participation of communities in politics 
and policy via their own culturally situated political institutions and social organizations. Many contain strong wording in this regard. Section III.1 of the Indigenous Accord, for example, states:

The Maya, Garifuna, and Xinca are authors of their cultural development. The role of the state is to help said development, eliminate obstacles to the exercise of this right taking the legislative and administrative measure necessary to fortify indigenous cultural development in all areas corresponding to the state and to assure the participation of the indigenous in the decisions relating to the planning and execution of cultural programs and projects through their own organizations and institutions.

The Accord continues in part IV.B.3:

Recognizing the role that corresponds to the communities, in the framework of municipal autonomy, to the exercise of the right of the indigenous peoples to decide their own priorities with respect to the process of development and in particular with relation to education, health, culture, and infrastructure. The government is committed to affirm the capacity of said communities in this manner.

In such a way, the concept of culture is mixed with the concept of development in national and international law. Both concepts are tied to human rights and with the idea of civic participation. A legal space for decentralized participation of indigenous peoples is provided by such instruments. This is not a sufficient condition, argue members of El Centro, however, to assure that such participation will occur. There is more involved in participation than the simple granting of the right to participate, as an $\mathrm{El}$ Centro document suggests:

Participation, in all its manifestations, must be a transformative action and practice of liberation initiated by the person, not for them, in which the oppressed and the excluded encounter conditions in which they can discover themselves reflexively as a subject of their own historical destiny. In this way, people discover paths to their own liberation through their own research and planning, and simply because freedom to meet in such a way is freedom to become master of your own decisions. In this sense, participation is not something that is granted, as one might mistakenly think, it is something that is won through constant struggle. (Chávez Cayax 2003, p. 21) 
True democratic transformative participation, this suggests, cannot occur without the formation of political subjects. Active groups of persons must initiate the processes of participation in which they discover and redefine themselves amidst the rubble of colonial and neoliberal ideology in which they may be currently trapped. The formation of political subjects, even within such an expansive legal architecture of participatory rights, requires the exertion of energy—a "constant struggle" (ibid.).

\section{Intervention, Organization, Political Subjects}

According to El Centro, the struggle to create active indigenous political subject is undertaken through social organization. As Bulux (2003) argues in one of the organization's documents:

Social organization is a comprehensive development process, which facilitates the study and understanding of the local context in formulating solutions. It also provides mechanisms that enable a community to meet collective challenges while maintaining its own identity, unity and solidarity. (p. 15)

Communities are not thought of as currently existing in a state of dysfunctional disorganization, however, and CSD does not require the imposition of organizations and institutions by outside experts. As Bulux (2003) explains:

In the community there exists a diversity of forms of organization-those which come from the communal authorities, associations, committees, cooperatives etc. ... It is from these cultural values of organization that culturally sustainable development must be realized. In this sense, sustainability must be understood as a value of the culture in that cultural practices already exist as responses that have been created and recreated through experiences of life and cohabitation with neighbors and with nature throughout their historical social development. (pp. 21-22)

Maya cultural institutions of governance, such as communal mayorships, then, can be employed as the main driver of CSD. This is not as simple a solution to problems of development as it may appear, however. Bulux (2003) explains that, 
Because of colonial policies of slavery and forced labour, the organization of Maya society suffered the disintegration of its social nucleus and therefore its social organization, which had been based in the value of common good and collective work. (p. 12)

Furthermore, as discussed in the previous chapter, both Maya cultural tradition and human rights conventions encourage the direct participation of women in political and planning processes. There are few organizations of Maya women existing in most communities, however. Considering this, "organization must be promoted amongst those sectors, such as youth and women, which may not be organized" (Bulux 2003, p. 15).

It is in these areas that the work of El Centro is situated. Through various interventions, the organization seeks to strengthen existing forms of social organization and to encourage the formation of political social subjects where they may not exist. These interventions do not simply target indigenous peoples and institutions, however, but also seek to create an acceptance of indigenous forms of social organization, in the spirit of mutual support, with official, modern, ladino-dominated state institutions such as municipal governments. This work is undertaken through four distinct projects at El Centro.

\section{Four Programmes}

In attempting to foster CSD, El Centro mobilizes four programmes in the Western Highlands. These are the Communal Mayorship programme, the Municipalities programme, the programme for Women and Youth, and the Research programme. All of these utilize participatory processes in the formation and building of capacities of local and municipal institutions and organizations. This is done through arranging information sessions, participatory workshops, diploma programmes, as well as community- and municipal-level meetings on topics that are important to the people of the Western Highlands.

\section{The Communal Mayorship Programme}

As discussed in the previous chapter, at the time of conquest, Mayan government involved communal mayorships which would undertake all the political, juridical, and administrative duties connected with parcialidades (administrative units of 300-600 people). These mayorships would 
convene from time to time at a regional level in an amaq' council. As a result of hundreds of years of Spanish colonial administration and institutionalized racism, the amaq' had disappeared by the time of the Peace Accords, and, although their existence remains widespread, the communal mayorships had been reduced to largely ceremonial status in a system dominated by a colonially imposed municipal governance structure (Hill 1989; Wittman and Geisler 2005; Barrios 1988). The Communal Mayorship programme is designed to remedy this by reasserting the cultural and political relevance of the institution in the eyes of indigenous peoples, ladinos, and official national, regional, and municipal governance institutions.

The initial step of this is called "first contact" by field technicians and coordinators at El Centro. In this step, a number of indigenous mayors from geographically close communities will be invited to a meeting at a nearby location. Members of El Centro will deliver a talk that is designed, first, to educate the mayors of the rights provided to them and their institution by the legal architecture discussed earlier in this chapter. Emphasis here is on the assertion that the communal mayorship has as much, or more, legal power than does the municipal mayorship. This is generally an unexpected revelation to the communal mayors.

Second, the communal mayors are asked to list all of the duties they currently perform in the communities. This list is usually substantial and covers juridical, political, and administrative responsibilities. Finally, the session concludes with an emotionally charged speech by the El Centro field technician who praises the resilience of the institution in the face of hundreds of years of colonial attempts to dissolve it, the cultural significance of the mayorship, and its democratic nature. "They tried to erase you," as Matea said in such a situation, "they still say you don't exist-but here you are." The purpose of El Centro - to assist the communal mayors-is asserted, and those mayors in attendance are asked what they would like El Centro to do for them. Often the mayors simply want to "know more about these laws."

After the first contact is completed, the communal mayors are often asked if they would like to attend a larger meeting-one which approximates an amaq' - of many communal mayors from across the region. These meetings are issue-based-perhaps covering topics such as health, education, or environmental degradation, but most commonly, of late, regarding the problems that communities are having with transnational mining companies. Information regarding the issue is provided by a 
member of El Centro. The mayors are split into a number of groups and are asked to construct strategy proposals regarding the issue. The merit of each proposal is discussed by the group, and consensus is sought regarding an overall strategy. All participants are paid enough to cover their travel, and they are fed. The meetings may last an entire day, so remuneration is essential given the loss of time that the mayors would otherwise have been spending on farm-work.

Although policy outputs of such meetings are important, the cultural and social significance of the meetings themselves must be emphasized. I was lucky enough to attend a regional meeting of mayors only two weeks after first contact had been established with five participants. I had also attended the first contact with these participants. What is striking anthropologically is that this, just as much as it is a policy meeting, is a social ritual in which subjectivities may be reformed. As a thought experiment, we could imagine what it could be like to be one of these communal mayors who just a few weeks before had accorded little value to their positions, then to be told that their institution was powerful enough to stand up to hundreds of years of planned ethnocide, and then told that their power is equal to that of the municipal government under national and international law. Finally, these mayors attend a meeting with forty to fifty other indigenous mayors who are actively constructing policy.

It is beyond the scope of this chapter to assess impacts of such activities. This would provide fertile ground for further study. But it should be made clear that this type of activity is designed to be "transformative" for participants. This type of participation is not consistent with liberal or republican forms of citizenship which presume a pre-formed human actor with stable beliefs and preferences as it engages in political participation. It is more congruent with thinking of Habermas (1984) or Rostboll (2008), who focus on the way in which such forms of participation act to transform subjectivities as they seek policy outputs, and assert that the overarching goal must be that all such participation be as egalitarian as possible. The goal for El Centro is to facilitate the creation of active political subjects who gain increasing respect for their own culture and institutions. Policy decisions created in such meetings are secondary to this "primary goal." 


\section{The Programme for Women and Youth}

This programme is similar to the Communal Mayorship programme in that it seeks to transform subjects into political subjects through rights education and social organization. The difference here is that the focus is on groups who are less likely to have pre-existing organizations and institutions. Women and Youth, it is insisted, have been excluded from political participation due to the importation of colonial cultural and political norms. The goal of the Programme for Women and Youth is to remedy this.

The first step undertaken by this project is to locate women's or youth groups that may be pre-existing in communities. Members of El Centro will ascertain through community interviews if such organizations are inclusive or exclusionary. Depending on this, activities will be organized within existing organizational structures or outside of them. In either case, the first order of business is rights education similar to that of the Communal Mayors Programme except that the focus is more on rights accorded to women and children within the national and international legal architecture. A second step is the organization of workshops based around a community issue. Similar to the case of the Communal Mayors, consensus on policy will be sought. Free access diploma programmes in democratic participation and rights are also offered. Again, the focus here is not so much on the policies agreed on, or number of diplomas awarded, but on the transformative nature of political participation.

The legitimacy of the Communal Mayorship is an important point that is maintained in this programme as well. The full electoral participation of all men, women, and children is located as a source of legitimacy. It is also reinforced that Mayan societies have historically sought equality and complementarity between genders and that women have the legal right to participate equally in the Communal Mayorship. Some communities have, in fact, elected woman mayors since El Centro began its work in the highlands, although this representation at meetings of Communal Mayors remains very low.

\section{The Municipalities Programme}

Similar to the other programmes, the Municipality Programme is centrally concerned with rights education. The increased autonomy granted to municipalities under national law is focused on, of course, but so too is the power granted to the Communal Mayorships. Great effort is taken to 
sensitize the municipal authorities to the equal status of the Communal Mayorships and the necessity that they be integrated into the municipal governing process. Assistance is provided by El Centro, when requested, with everything, from budgeting to the integration of community groups to conflict resolution and legal interpretation.

To have a municipalities programme was not of initial priority to $\mathrm{El}$ Centro, but members of the organization soon realized it to be necessary. As Sofia explains,

When we began work, we worked only with the population, with civil society, with organizations, with the communal authorities, but only with the population. Therefore it seemed illogical to work with municipal governments. But the municipal government is a place where people take proposals. Therefore the work of our program now is to make the municipal governments aware of the need to open spaces [to dialogue and receive proposals from the population]. The problem is that many municipal governments are authoritarian, and remain closed. They do not accept proposals from the population. So our work involves facilitating a space for dialogue between the municipal government and the population, and to create acceptance of these proposals with the departmental and national governments if need be.

This sensitization of the need of municipal, departmental, and national governments to dialogue directly with the population regarding policy is now a fundamental part of El Centro's CSD strategy. Most of the focus in this regard is concentrated in the relationship between the communal mayorships, women's and other civil society groups, and the municipality. The idea is not to replace the state and municipality with a romanticized preColumbian institution, but to create a space in which all of these institutions may dialogue and engage in mutual change, exchange, and support. It is with respect to the municipalities programme that we can see a fundamental goal of El Centro - to create an organic and mutable form of decentralized democracy which combines indigenous and modern (state) institutions in a sphere of dialogue and mutual change. This implies that indigenous culture and cosmovision be integrated into policymaking beginning at the municipal level, but at departmental and national levels as well.

\section{The Research Programme}

El Centro has a need to investigate its own activities and evaluate their effectiveness. This, however, is not the primary purpose of the Research 
Programme. This initiative is more centrally interested in facilitating a transformative form of participation through participatory research within communities, and encouraging knowledge-sharing amongst them. This is clear when we consider the following text, contained in the prologue of one of El Centro's research documents on community conflict over water, which outlines the five main goals of the research process:

The first, to reconstruct the history of the experience; the second, to approximate the collective reflection of those subjects who participated in the same [events], third; to communicate the results so that they can serve as inspiration, orientation and foundation for the attitudes and actions of future generations; fourth, for the construction of collective knowledge; and fifth, so that it may serve as orientation and example for other communities in the solution of their own conflicts, from their own reality, cosmovision and practice. (CPD 2008, p. 7)

The process of research and distribution of published materials is at least as important as their textual content. The research process is participatory-involving focus groups and qualitative interviews. The final representation of events is presented and validated or changed by community members. In the end, travel is paid for to allow community members to attend a publication release event in which each attending member is presented a copy of the research.

The case of the (2008) publication of Conflictos Comunales por el Derecho al Agua (Community Conflicts over the Right to Water) serves as a fitting example. A number of communities in the municipality of Palestina do Los Altos were involved in a long-standing conflict over rights of access to a natural water source. The conflict, which lasted from approximately 1988 to 2002, was typified by violence, incarcerations, kidnappings, split communities and families, as well as public protest. The issue cut across the jurisdiction of several communal mayors, two municipalities, and involved a development plan implemented with little consultation by an international development organization (CARE). After years of sometimes violent conflict, a solution was created with assistance from $\mathrm{El}$ Centro. Through cooperation, negotiation, and compromise, an agreement between municipal (viewed as "State") authorities and the communal mayors was achieved. The agreement was the result of several workgroups, meetings, public consultations, and participatory budgeting initiatives (CPD 2008). 
The history of the conflict was then researched in a participatory manner by El Centro. The resulting document recounted the history as constructed by participants. A number of conclusions were also formulated. These included an assertion that state action is often "an imposition ... with respect to community-based forms of organization." This, it was argued, "contrasts with the communities own forms of organization, specifically the communal mayorship which has its own norms, principles, and values with which to resolve disputes" (p. 53). It was also argued that the time of conflict was also a time of learning for local authorities, as they

learned to negotiate with the institutions of the state, with all of its difficulties, something that none had done before the conflict. They also learned to coordinate the actions of state institutions with the ancestral institutions represented by the communal mayorships. (p. 53)

Furthermore, it was explained that "the communities undertook participatory budgeting, something that had not even crossed their minds before" (p. 56), and that, throughout the process, "the Communal mayor did not complete a roll only as 'auxiliary' to the municipal mayorship" but was engaged as equal partner (p. 56). It was argued that the conflict and resolution fostered not only the "construction of social capital" (p. 58), but also the "construction of collective conscience [as] ... the experience served to promote the understanding that collective well-being should always prevail over individual interest" (p. 59). The analysis ended with a strong affirmation of the authority and legitimacy of the communal mayorship:

The efforts made to reclaim the role of communal Mayors reflect the roles they are playing today. The institution has transcended the role of assistant to the municipal mayor to perform roles of local leader and administrator of the community in the political aspects and administration of justice. This is evidence that it is not the laws that are imposed by the state that govern the development of communities, but is their own historical evolution that is shaping social relations according to their own culture. (p. 59)

The way in which these findings are disseminated is of upmost importance. The history and analysis were published in a small book. A public event was planned in Quetzaltenango-Guatemala's second-largest cityand nearly 100 delegates were invited from all of the communities 
involved. Travel expenses were covered for attendees, and food was provided during the half-day event. The communal mayors and municipal mayors involved in the conflict spoke about the experience, as did members of El Centro and other community members. In the end, community members in attendance were called, each by name, to receive a personal copy of the book, complete with handshakes from members of El Centro, and a photo in each case. Recipients were men, women, and children from the communities. They were receiving what amounted to an award for their ingenuity and achievement. The point, as was explained to me later, was to instil confidence in local communities of their competence and ability to direct their own development. Copies of the book were also given to community representatives for free distribution in the communities. Finally, such publications are distributed to other communities in the highlands-especially to communal mayors—in order to share these lessons.

\section{Maya versus the Mine}

The issue of mining has become central to the activities of El Centro, so it serves well as example within which the theory and practice of the organization may be contextualized. The Central America region, Guatemala in particular, is witness to a continuing proliferation of conflicts between communities and transnational mining interests. Since the 1996 Peace Accords were signed, for example, there have been 380 solicitations for mining rights to the government of Guatemala (CPD 2009, p. 22). No attempt will be made here to explore the issue deeply in all its facets nationally, internationally, or locally. What will be presented is a brief overview of the relationship of El Centro to the mining conflict involving the municipality of Sipacapa in the department of San Marcos.

El Centro began working with women, youth, and the communal mayorship of Sipakapa in 2004. It was not until the following year that the issue of mining arose, and at this time it was the communal mayorship that brought it to the attention of the organization. In 2003, the Canadian mining company Montana (a subsidiary of Glamis Corp., and then GoldCorp) had been granted, without community consultation, a large gold-mining concession in the Western Highlands. In all, 85 percent of the concession lay in the municipality of San Miguel, and 15 percent in Sipacapa. A total of 1 percent of the proceeds from the concession was to be accrued by the national government, and the remaining 99 percent to 
the company. No royalties from the resource extraction were to be granted to the community (CPD 2009; Yagenova and Garcia 2009).

In 2005, aided by investment funds from the World Bank, Montana began construction of the Marlin Mine in San Miguel. In the time between the granting of the concession and the beginning of construction, residents of Sipacapa had begun to educate themselves about the environmental and health risks associated with mining, and about their legal rights of consultation in the granting of such concessions. This community-led research was facilitated by El Centro and a number of other human rights and environmental organizations such as Madre Selva. As Roberto explains, they were trying "to generate a process of understanding in the population, and to give them the elements necessary to defend their collective rights." Growing community concern led to activism against the development of the mine in nearby San Miguel and its planned expansion into Sipacapa (CPD 2009). The precautionary concerns, which soon manifested in reality in San Miguel, were material and cultural as Roberto explains:

When we have 30 kilometres of mining exploitation, it will imply that we are going to see 30 kilometres of territory in these municipalities without natural areas, without natural resources, without forests, without biodiversity, without fauna, without flora, without anything. And apart from this with certain contamination of water-not just the rivers but the water table, the subterranean water will be contaminated as well. More than this, there are illnesses; these have actually appeared [in San Miguel]. Many illnesses of the skin have appeared and we believe this to signal a great risk to the lives of the people. In the theme of culture, for example, as well: there is a destruction of the land and the land is conceived as the mother for the indigenous peoples because it is what produces all that sustains and provides nutrition for the population ... [This therefore] can affect as well spirituality, cosmovision. We speak of a culturally sustainable development from the perspective in the indigenous peoples-in these municipalities everything is the opposite.

This corresponds with the assertions of lawyers working with the community, who argued that,

the company is in flagrant violation of the UN International Covenant on Economic, Social, and Cultural Rights and ILO Convention 169 Concerning the Rights of Indigenous and Tribal Peoples in Independent Countries. The company has also infringed local property rights, including the use, posses- 
sion, and administration of local indigenous land and territory. The mining project has also trampled on the patrimonial right of San Miguel and Sipacapa to decide on whether to issue mining licenses that pose risks to health, the environment, security, social and cultural life as well as the right to the free self-determination of the people. (Yagenova and Garcia 2009 , p. 165)

In addition to this, physical damage from blasting at the mine has appeared in the form of cracks in housing structures (Marroquín 2009).

The communal mayors and other community groups sought help from the municipal mayor's office, but received only the response that the mining issue was beyond its jurisdiction. All the while, connections were being established between local community groups, national organizations such as Madre Selva, and international groups such as the Indigenous Peoples Council of Central America. Concerted activism was apparent in 2005 as citizens of Los Encuentros-a municipality hours from Sipacapa-cooperated in a protest which blocked the transport of necessary materials for the construction of the mine. In that same year, the community of Sipacapa held a public consultation in which they declared a ban on mining under the auspices of ILO 169 and the authority of the traditional communal authorities (CPD 2009; Yagenova and Garcia 2009).

The legality of the consultation was challenged on many levels by the mining company. The most notable of these challenges was a grievance filed on the grounds that the consultation was unconstitutional. The Guatemalan Constitutional Court on 8 May 2007 granted that the consultation was legal, but only as just that-a consultation-and was not legally enforceable since subterranean resources are constitutionally the property of the national government (OCG 2010). Shortly after this, the same court found, however, that the national mining law was unconstitutional in that it violated environmental stipulations in the constitution. In 2010, a group of over 80 civil society organizations including El Centro officially petitioned the national government to suspend mining operations in the country, pending community consultations and impact assessments (Prensa Libre 2010). Later that year, just as members of El Centro were meeting in Canada with indigenous peoples who had conflicts with resource extraction under the invitation of the Canadian Ambassador to Guatemala, a Canadian Supreme court ruling required Canadian extractive industries to abide by stricter ethical and environmental guidelines (Ljunggren 2010). Finally, in June of 2010, the Guatemalan government 
officially enforced the closure of the Marlin Mine, pending more research into the environmental and social consequences of mining (Marroquín 2009). This closure was suspended in 2011 when the mine resumed full production. The Marlin Mine finally closed permanently in 2017, somewhat due to political pressure, but more so due to the near-complete extraction of all gold. All mining equipment has been moved to a new mine, which is currently beginning production in Cerro Blanco, Guatemala.

The saga of opposition to the Marlin Mine is complex. There are many researchers that will no doubt craft exemplary accounts of the issue. There are two import points for the current discussion that involve, first, the way in which mining was perceived as a threat to CDS in the Western Highlands, and, second, the way in which communities, and especially communal mayors, organized with the assistance of a large network of rights organizations-a processes to which El Centro was integral.

Regarding the first point, there were five main damages that emanated from the mining project which were perceived by the community and $E l$ Centro. First, there was the damage of disrespect associated with the community not being consulted regarding plans to initiate mining on communal territory. Second, there were damages associated with contamination of water supplies and associated illness. Third, there were physical damages to housing structures. Fourth, there were environmental damages, as the ecosystem near the mine was completely destroyed. Finally, and related intimately to this, is the personal felt cultural damage inflicted indirectly as environmental degradation impacted indigenous subjectivities which have a close felt relationship with their natural environments, as Roberto's earlier statement suggests. These damages are material, spiritual, and cultural, but each is perceived as real and important. And, as Roberto has suggested, they all run contrary to a development that is culturally sustainable, despite promises of potential employment. Importantly, at no point has community opposition to the project been undertaken with the goal of receiving economic proceeds from the mining. This reveals that economic incentives are low on the list of priorities of community members compared to the other damages listed earlier.

The second point-regarding the reaction or the communities to these perceived damages - is equally revealing of the multifaceted nature of $E l$ Centro's theory of development. Resistance to the project was undertaken in multiple ways - through press, through protest, through the judicial system, but key to this was the building of capacities of pre-existing 
cultural institutions such as the communal mayorship. El Centro does not measure success in the conflict by noting constitutional court decisions, but by recognizing the capacities of environmental monitoring and political action that have been developed in the communities during the process, as well as the increased status of the communal mayorship that has been achieved (CPD 2009). Underlining this, it was the community that introduced mining as a problem to El Centro in the first place, and the community of Sipacapa and many others in the Highlands have made this point strongly enough that mining has become the main issue around which CSD work revolves at the organization.

\section{ConClusion}

Any attempt to succinctly summarize the thinking of El Centro must begin with the cosmovision. The essence of Maya cosmovision is that the three discursive, analytical categories of nature, culture, and human are inseparable-that they are one. Cosmovision is practically inseparable from culture-it is the way of seeing that is predominant in a particular cultural setting. It also prescribes, however, ways of acting, and all ways of acting are thought to be consistent with the cosmovision, since it is the core of the culture. Appeals by El Centro to Mayan cosmovision may be thought as attempts to point out that threats or damages to culture or nature are interpreted as real human damages by subjects that are situated within Mayan culture, and that Mayan subjects, by virtue of their intimate relationship with nature, are culturally predisposed to be effective stewards of the local natural environment.

The "subjects" that are evoked here may be single persons, but are just as likely to be groups of persons. This ambiguity exists partly because the concept of an individual, which is divisible from the community, is not consistent with Maya cosmovision. Subjects are created by their material and cultural environment. Importantly, this implies that values, valuations, beliefs, tastes, and utility functions (to use the language of neoclassical economics) are viewed as the products of culture, and this culture is not understood simply as the product of self-interested interaction as new institutional economics tends to suggest. Culture exists for culture's sake. "It has its own value," as Mario has suggested.

This depiction need not imply that cultures and subjects are stagnant and immutable. Cultures are constantly mutating, and subjects may have agency to change their cultural situation, just as they may have agency to 
change their material situation. Cultures, it is asserted, are constantly informed and re-formed from their interaction with their "outsides"through the blurring of their edges. It is the agency of social subjects within this process that is thought to determine the outcome of the interaction.

It is argued by members of El Centro that agency, however, is not equally distributed across the globe, within Guatemala, or within the Western Highlands. Material deficiencies are thought to impact the agency that a subject has to change its discursive and material environments, so are less tangible elements such as racism and cultural devaluation. The agency of indigenous Mayan subjects is promoted by the organization through measures that attempt to assure that food, health, and clean water are attainable to subjects but also through increasing indigenous peoples' self-valuation of their own culture and sensitizing ladino subjects and state institutions to the same. This is attempted through El Centro's four major programmes which deal with communal mayorships, women and youth, municipalities, and research.

It is essential to note that claims that Maya subjects are culturally predisposed to environmental consciousness should not be taken to imply that all indigenous Maya men, women, children, or even communal mayors exhibit this behaviour and feel this connection. Of course, it is understood by members of El Centro that many do not. But the underlying logic of CSD is this: the cultural tradition of the Mayan cosmovision gives much more credence to the unity of human/culture/nature and the place of humans as "givers of praise, givers of respect, providers, and nurturers" than do Western enlightenment culture with its Newtonian model of the universe, consumer capitalist culture with its view of the environment as a resource (whether or not that resource must be sustained for the benefit of future generations), or related forms of Christianity which tend to depict the natural world as a gift from God to be exploited by Man (Molesky-Poz 2009, p. 38). The simultaneous work of valorizing Maya culture while opening space for indigenous political action is undertaken in order to create political subjects that value Maya cosmovision more intensely. These resultant Maya political subjects, it is assumed, will therefore be environmental subjects by virtue of this increased valuation of the cosmovision.

This is simultaneously cultural change and cultural continuity, and it would not be possible if Maya cosmovision was not already ingrained, if only partially, in the subjectivities of indigenous people. For proof that it 
is, members of El Centro point to the continued existence of a wide variety of Maya cultural practices-from the widespread use of traditional clothing and language to the persistence of indigenous religious practices and the continued relevance of the communal mayorship. The programmes of cultural valourization are not considered impositions because they resonate with the existing cosmovision of the indigenous peoples of the Western Highlands. In cases where the cosmovision is lost to a greater extent, such as could be argued to be the case in the town of Tecpan (Hill 1989; Wittman and Geisler 2005), decentralization would be instead promoted via the municipal government.

The revalorization of Mayan culture, the amplification of indigenous political agency, and the reassertion of rights to resources and territorial control that are implied in this process are linked to the promotion of grassroots democracy which is thought to be the prerequisite to any meaningful sustainable development plan. Centuries of racism, colonialism, and neocolonialism have robbed indigenous Maya not only of their culture, and their political voice, but also of the fundamental sustenance necessary to assert their own culture and their own idea of development. The programme of El Centro is designed to promote a foundational level of discursive and political equality which includes access to material resources-or at least not the continued degradation of existing resources (by mining operations, e.g.). The guiding principal is that of equality of the capacity to participate in decision-making, policy, and planning processes, as well as the communicative production of culture. Only once this is achieved will culturally sustainable development initiatives be possible.

In such a climate, it is argued by members of El Centro, development plans, governing policies, and systems of cultural understanding implicated in development processes would be authored substantially by the communities of the Western Highlands themselves. This does not necessarily suggest that this authorship not be undertaken in cooperation with the Guatemalan State, foreign donors, or transnational corporate interests, nor does it prescribe insulation from global cultural flows. It does suggest a fundamental and ongoing commitment to struggle for equality so that such interactions remain democratic.

In this we can see the solving of a suggestive riddle: why would an organization that is centrally concerned with culturally sustainable development be called the Pluricultural Centre for Democracy? The answer is that CSD is predicated on democracy in the deepest sense. Or, rather, that development is democracy. This democracy is not limited to the formal liberal 
architecture of municipal, national, and departmental elections with free press and active civil society which exerts pressure on decision-makers in government. This Maya form of democracy involves the devolution of decision-making power to local communities, as well as the valorization, continued transformation, and respect for diverse cultural institutions and schemes of understanding. It is a decentralized and pluricultural democracy-one in which human agency and human subjectivities are in constant flux, but also rooted meaningfully in the past. It is also a democracy whose maintenance requires constant struggle.

\section{REFERENCES}

Barrios, L. (1988). La Alcaldía Indígena en Guatemala. Guatemala City: Instituto de Investigaciones Económicas y Sociales (IDIES): Universidad Rafael Landivar.

Bulux, C. R. G. (2003). Organización y Desarrollo Culturalmente Sustentable: Refleciones a Partir de Ambito Municipal. Quetzeltenango: El Centro Pluricultural para la Democracia.

Chávez Cayax, E. O. (2003). La Participación Democratica para el Desarollo Culturalmente Sustentable. Quetzeltenango: El Centro Pluricultural Para la Democracia.

El Centro Pluricultural para la Democracia (CPD). (2008). Conflictos Comunales por el Derecho Humano al Agua. Quetzeltenango: CPD.

El Centro Pluricultural para la Democracia (CPD). (2009). Systemitización de las Experiencias de Consultas Comunitarias sobre El Tema de Minería, en Los Municipalidades de Sipacapa, San Marcos y Colotenango, Huebuetenango. Quetzeltenango: CPD.

Habermas, J. (1984). The Theory of Communicative Action, Vol. 1. Thomas McCarthy (Trans.). Boston: Beacon Press.

Hill, R. (1989). Social Organization by Decree in Colonial Highland Guatemala. Ethnohistory, 36(2), 170-1998.

Ljunggren, D. (2010, May 14). Canadian Court Ruling Clarifies Mine Permit Process. Reuters.

Marroquín, A. (2009, November 16). Responsabilizan a Montana Exploradora Por daños en Casas. Prensa Libre.

Molesky-Poz, J. (2009). Contemporary Maya Spirituality: The Ancient Ways are not Lost. University of Texas Press.

On Common Ground Consultations Inc. (OCG). (2010). Human Rights Assessment of Goldcorp's Marlin Mine. Vancouver: OCG.

Prensa Libre. (2010, April 6). Unas 80 Organizaciones Piden Suspender Actividad Minera en el País. 
Rao, V., \& Walton, M. (2004). Culture and Public Action: Relationality, Equality of Agency, and Development. In V. Rao \& W. Walton (Eds.), Culture and Public Action (pp. 3-36). Stanford: Stanford University Press.

Rostboll, C. F. (2008). Deliberative Freedom. Albany: State University of New York Press.

Wittman, H., \& Geisler, C. (2005). Negotiating Locality: Decentralization and Communal Forrest Management in the Guatemalan Highlands. Human Organization, 64(1), 62-74.

Yagenova, S. V., \& Garcia, R. (2009). Indigenous People's Struggles Against Transnational Mining Companies in Guatemala: The Sipakapa People vs Goldcorp Mining Company. Socialism and Democracy, 23(3), 157-166.

Open Access This chapter is licensed under the terms of the Creative Commons Attribution 4.0 International License (http://creativecommons.org/licenses/ by $/ 4.0 /$ ), which permits use, sharing, adaptation, distribution and reproduction in any medium or format, as long as you give appropriate credit to the original author(s) and the source, provide a link to the Creative Commons licence and indicate if changes were made.

The images or other third party material in this chapter are included in the chapter's Creative Commons licence, unless indicated otherwise in a credit line to the material. If material is not included in the chapter's Creative Commons licence and your intended use is not permitted by statutory regulation or exceeds the permitted use, you will need to obtain permission directly from the copyright holder.

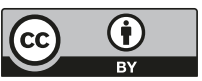

